\title{
An Investigation of the Relationship between Language Learning Strategies and Learning Styles in Turkish Freshman Students
}

\author{
Özgül Balc1 ${ }^{1}$ \\ ${ }^{1}$ School of Foreign Languages, Necmettin Erbakan University, Konya, Turkey \\ Correspondence: Necmettin Erbakan University, School of Foreign Languages, Meram Campus, 42090 Meram, \\ Konya, Turkey. Tel: 90-332-3238220/5771. E-mail: obalci@konya.edu.tr
}

Received: January 30, 2017 Accepted: March 4, 2017 Online Published: March 6, 2017

doi: 10.5539/elt.v10n4p53 URL: http://dx.doi.org/10.5539/elt.v10n4p53

\begin{abstract}
The purpose of this study is to determine the relationship between the language learning strategies of freshman students and their learning styles. This study is a descriptive research and employs a relational screening model. Participants of the study were 328 freshman students majoring in different fields at Necmettin Erbakan University Ahmet Keleşoğlu Faculty of Education in Turkey. Data were collected via Turkish version of "Strategy Inventory of Language Learning (SILL)", originally developed by Oxford (1990) and adapted into Turkish by Cesur and Fer (2007) and "Big 16 Learning Modality Inventory" by Şimşek (2002). Data were analyzed by using descriptive statistics and the Pearson's correlation coefficient. The research results revealed that learning styles have a significant effect on language learning strategy use. The results and implications of the study are discussed and suggestions for future research are offered.
\end{abstract}

Keywords: language learning strategies, learning styles, foreign language learning

\section{Introduction}

Individual differences have been a remarkable point in language learning as in the other fields of education. Learning styles and strategies can be said to be the most outstanding, discussed and researched factors among all other learner differences in mainstream literature on language learning (Brown, 2000; Ehrman, Leaver, \& Oxford, 2003; Oxford, 2001; Peacock, 2001). Furthermore, Oxford (2001) explicitly suggests that language learning styles and strategies are among the key factors in determining the quality of student learning in second and foreign language (L2).

Learning styles are defined as "the general approaches - for example, global or analytic, auditory or visual - that students use in acquiring a new language or learning in any other subject" Oxford (2001, p. 359). Also, Brown (2000) defines learning styles as individual characteristics of intellectual functioning which are consistent and rather enduring. One of the leading researchers in the field, Reid (1995) defines learning styles as the internal characteristics often used unconsciously during receiving and processing new information.

Many researchers have examined different aspects of learning styles. As one reviews the literature on learning styles, it becomes apparent that different terms are alternatively used for the concept of learning styles. Ehrman et al. (2003) emphasize that learning style, cognitive style, personality type, sensory preference and modality are some of the terms often used in broad strokes and interchangeably by different researchers in the field. As Reid (1995) points out, the differing terminology used in labeling different aspects of learning styles by different researchers has caused obscurity in the area which has ended up with impractical and inaccessible research results in practice. The researcher describes learning styles in three major categories which are especially relevant and applicable in English as a Second Language (ESL) and English as a Foreign Language (EFL) contexts: cognitive learning styles, sensory learning styles and personality learning styles.

Oxford is one of the researchers who have worked through learning styles in the context of L2 learning. Oxford (2001) presents four dimensions of learning style which are thought to be the most relevant to L2 learning, namely: sensory preferences, personality types, desired degree of generality, and biological differences. In literature, the most commonly used and highly important learning styles categories for L2 learning can be said to be based on sensory preferences (Oxford, 2001; Reid, 1995; Rossi-Le, 1995). Oxford (2001, p. 360) defines sensory preferences as "physical, perceptual learning channels with which the student is the most comfortable" 
and analyzes sensory learning preferences in four main areas: visual, auditory, kinesthetic, and tactile. Rossi-Le (1995) uses the term perceptual learning style and defines it as "an individual's preferred mode for perceiving, organizing, and retaining information" (p. 118). Ehrman et al. (2003) specify that having the opportunity to learn through their preferred learning styles, students will get the advantage of a more flexible and student-friendly learning environment, resulting with better learning and performance. Also, teaching in a balanced style in the EFL classes is largely recommended (Peacock, 2001).

Learning strategies are usually observable learning behaviors associated with learning styles (Ehrman et al., 2003). Oxford (2001) defines learning strategies in a language learning environment as "specific behaviors or thought processes that students use to enhance their own L2 learning" (p. 362) and emphasizes that they are far more specific than learning styles. Also, Brown (2000) defines strategies as specific techniques employed to solve a particular problem which might vary according to time and situation. Oxford (1990) indicates that learning strategies are of great importance, especially for language learners because they enhance active, autonomous involvement in language learning process and this is important for developing communicative competence, which is the ultimate goal of language classes. Reid (1995) draws the important distinction between learning styles and strategies and describes learning strategies clearly as study skills that can be taught and often used consciously to improve learning. Fewell (2010) indicates that language learning strategies are thought to be an "effective and workable" (p. 159) factor in language learning process among other important factors affecting L2 acquisition because they are controllable and it is possible to manipulate and manage strategies in order to improve language learning. Oxford's (1990) language learning taxonomy is thought to be "perhaps the most comprehensive classification of learning strategies to date" (Ellis, 1994, p. 539). Oxford (1990; 2001) has identified and explained six major types of learning strategies in terms of L2 learning: cognitive, metacognitive, memory, compensatory, affective, and social. Chamot (2004) characterizes strategic learners as learners having metacognitive knowledge about their own learning processes and the ability to use strategies properly in accordance with the task at hand and their own learning strengths.

The relationship between learning styles and strategies in language learning field is also emphasized in literature. Reid (1995) suggests that one of the fundamentals of learning styles in the ESL/EFL classroom is the fact that students' learning strategies are linked to their learning styles. Also, Ehrman et al. (2003) agree on this relationship by asserting that styles and strategies are often seen interrelated, that is, strategies are generally 'overt learning behaviors' (p. 315) indicating learning style preferences of students. Oxford (2001) points out the great value of fitting L2 instruction and strategy instruction to learners' learning style preferences. The researcher also asserts that the ability to self-regulate learning is associated with choosing the strategies compatible with learning style and the task. It is clearly indicated that learning style preferences has an influence on the use of language learning strategies (Oxford, 2003; Rossi-Le, 1995). In literature, there are some (though limited number of) studies which have found that there is a significant relationship between language learning strategies and learning styles. Rossi-Le (1989) found significant relationships between language learning strategies and learning styles, with the strongest correlation observed between visual learning style and visualization strategies. Ehrman and Oxford (1988) also found some significant relationships between the use of language learning strategies and psychological types. Also, Ehrman and Oxford (1990) reports differences among language learners' uses of language learning strategies by psychological-type category. On the contrary, in a study by Rahimi, Riazi, and Saif (2008) it was reported that learning style did not predict the use of language learning strategies for a group of EFL learners.

Individual differences are thought to be a complex issue in language learning literature which needs further investigation because of insufficient results (Ehrman et al., 2003). Moreover, Reid (1995) remarks that the area of learning styles and the difference between learning styles and strategies has often been complicated and unclear. Also, the relationship between the use of language learning strategies and some other variables such as gender, proficiency, age, and self-efficacy and other variables has been the focus of considerable body of research (Magogwe \& Oliver, 2007; Salahshour, Sharifi, \& Salahshour, 2013; Y1lmaz, 2010) in recent years. Because of the scarcity of the research in language learning literature on the relationship between learning styles and language learning strategies, it is believed that further research would be of the great need. Additionally, as Fewell (2010) points out, studies investigating language learners in a foreign language environment are quite rare when compared to large amount of research performed in a second language environment. So, in this study, through a literature review of related studies, it is aimed to shed more light on the relationship between language learning strategies and learning styles of students.

Based on the aim of the study, the following research question was formulated:

- What language learning strategies do university students report using? 
- What learning styles do university students prefer?

- Are there any relationships between learning style preferences and language learning strategy use of university students?

\section{Method}

\subsection{Research Design}

This research is a descriptive study that adopts a relational screening model in order to determine the relationship between the language learning strategies of freshman students and their learning styles.

\subsection{Instrumentation and Procedure}

Two instruments were employed to collect data for the present study. First, Big16 Learning Modality Inventory (Şimşek, 2002) was used to identify learners' dominant learning style. Big16 Learning Modality Inventory is used to identify students' learning modalities, namely kinesthetic, auditory and visual. Şimşek (2002) reported a Crombach's alpha reliability coefficient of 0.84 for the total scale, 0.68 for kinesthetic subscale, 0.77 for auditory subscale, and 0.79 for visual subscale. Internal consistency for the present sample was as follows:

Learning style

Cronbach's Alpha

Kinesthetic 0.69

Auditory

Visual

Total Scale

Secondly, The Strategy Inventory of Language Learning (SILL), originally developed by Oxford (1990) and adapted to Turkish by Cesur and Fer (2007), was used to assess learners' language learning strategy use. SILL is a self-report questionnaire used to determine how often each group of strategies is used for learning English. Cesur and Fer (2007) reported a Crombach's alpha reliability coefficient of 0.92 for the total scale and Crombach's alphas ranging from 0.59 to 0.86 on subscales. Internal consistency for the present sample was as follows:

$\begin{array}{ll}\text { Strategy } & \text { Cronbach's Alpha } \\ \text { Memory strategies } & 0.79 \\ \text { Cognitive strategies } & 0.88 \\ \text { Compensation strategies } & 0.76 \\ \text { Metacognitive strategies } & 0.91 \\ \text { Affective strategies } & 0.73 \\ \text { Social strategies } & 0.63 \\ \text { Total scale } & 0.95\end{array}$

Data collection took place in the spring semester of the academic year 2012-2013. Both self-administered questionnaires were distributed to freshman students at the faculty during the Foreign Language II (English) course and they took approximately 20-30 minutes to complete. Students were informed that participation in the study was voluntary.

\subsection{Participants}

The subjects were 328 students (see Table 1) studying in different departments in Ahmet Keleşoğlu Faculty of Education at Necmettin Erbakan University located in Konya, Turkey. Participants' ages range from 18 to 21+ years (see Table 2). All the students were taking Foreign Language I and II courses as part of their curriculum. Foreign Language Course was a compulsory, year-long course for the first-year students at the faculty. 
Table 1. Number of participants by gender

\begin{tabular}{lllll}
\hline & Frequency & Percent & Valid Percent & Cumulative Percent \\
\hline Male & 103 & 31.4 & 31.4 & 31.4 \\
Female & 225 & 68.6 & 68.6 & 100 \\
Total & 328 & 100 & 100 & \\
\hline
\end{tabular}

Table 2. Number of participants by age

\begin{tabular}{lllll}
\hline Age (years) & Frequency & Percent & Valid Percent & Cumulative Percent \\
\hline 18 & 65 & 19.8 & 19.9 & 19.9 \\
19 & 150 & 45.7 & 45.9 & 65.7 \\
20 & 81 & 24.7 & 24.8 & 90.5 \\
$21+$ & 31 & 9.5 & 9.5 & 100 \\
\hline
\end{tabular}

Table 3. Descriptive statistics of participants' language learning strategy use by gender

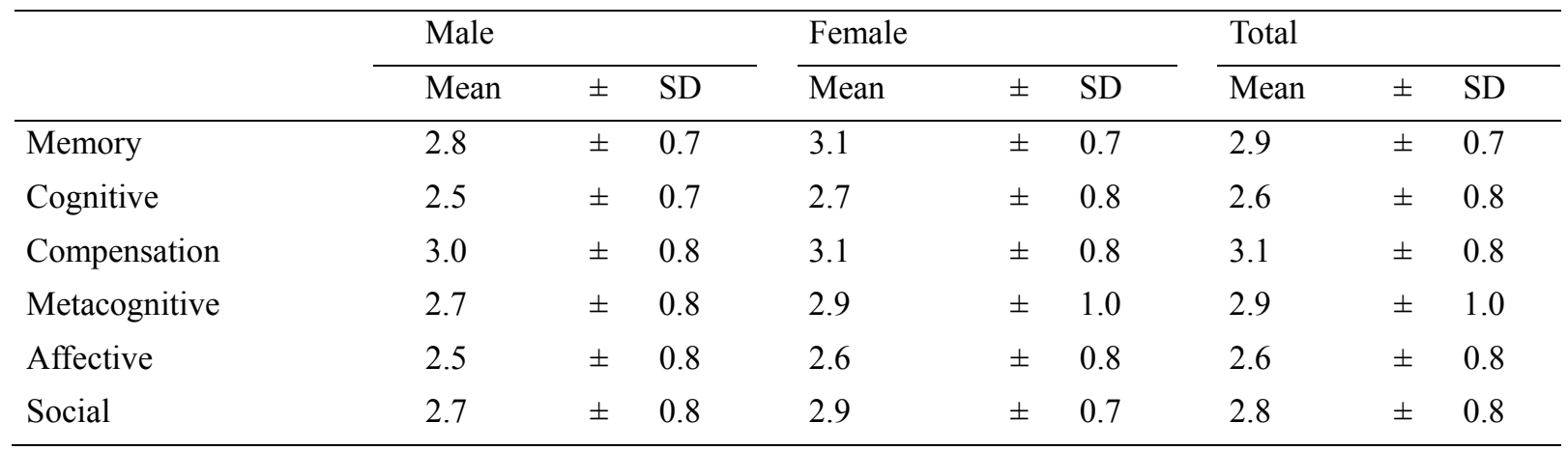

As Table 3 shows, compensation strategies are the most frequently used strategies among the male students, followed by memory, metacognitive and social, cognitive and affective strategies respectively. Also, compensation and memory strategies are the most frequently used strategies among the female students, followed by metacognitive and social, cognitive and affective strategies respectively. Oxford (1990, p. 300) explains that the overall average tells how often you use strategies for learning English. As each part of the SILL represents a group of strategies, the averages for each part of the SILL show which group of strategies are used the most for learning English. The mean scores that fall between 1.0 and 2.4 are defined as low level strategy use, $2.5-3.4$ as medium level use, and $3.5-5.0$ as high level strategy use. So, it can be said that both male and female students have medium level language learning strategy use.

Table 4. Descriptive statistics of learning style preferences by gender

\begin{tabular}{|c|c|c|c|c|c|c|c|c|c|}
\hline & \multicolumn{3}{|l|}{ Male } & \multicolumn{3}{|c|}{ Female } & \multicolumn{3}{|l|}{ Total } \\
\hline & Mean & \pm & SD & Mean & \pm & SD & Mean & \pm & SD \\
\hline Kinesthetic & 10.6 & \pm & 6.9 & 8.1 & \pm & 7.6 & 8.9 & \pm & 7.5 \\
\hline Auditory & 10.3 & \pm & 6.6 & 11.5 & \pm & 6.2 & 11.1 & \pm & 6.4 \\
\hline Visual & 14.2 & \pm & 6.9 & 15.4 & \pm & 5.6 & 15.1 & \pm & 6.1 \\
\hline
\end{tabular}

As Table 4 shows, visual learning style is the most preferred learning style among the male students, followed by kinesthetic and auditory learning styles. Similar to the male students, visual learning style is the most preferred learning style among the female students, followed by auditory and kinesthetic learning styles. 


\subsection{Data Analysis}

The data were tested for normal distribution with the Kolmogorov-Smirnov test and for homogeneity of variances with Levene's test. Students' learning styles and strategies were analyzed by descriptive statistics (mean, frequency, percentage and standard deviation) and the Pearson's correlation coefficient was used to determine the relationship between learning styles and language learning strategies with the SPSS 16.0 for Windows statistical package. Statistical significance was set at a $\mathrm{P}<0.05$ level.

\subsection{Assumptions and Limitations}

This study is limited to the data obtained from 328 volunteer students studying in different departments in Ahmet Keleşoğlu Faculty of Education at Necmettin Erbakan University during the spring semester of academic year 2012-2013. Also, it is assumed that the respondents answered the questions honestly and accurately.

\section{Results}

In this section, results pertaining to the participants' learning styles, language learning strategy use and the relationshisp between learning styles and strategies are presented.

Table 5. Descriptive statistics of participants' language learning strategy use

\begin{tabular}{lllll}
\hline Strategies & Frequency & Percent & Valid Percent & Cumulative Percent \\
\hline Memory & 86 & 26.2 & 26.2 & 26.2 \\
Cognitive & 11 & 3.4 & 3.4 & 29.6 \\
Compensation & 108 & 32.9 & 32.9 & 62.5 \\
Metacognitive & 58 & 17.7 & 17.7 & 80.2 \\
Affective & 26 & 7.9 & 7.9 & 88.1 \\
Social & 39 & 11.9 & 11.9 & 100 \\
\hline
\end{tabular}

As Table 5 shows, compensation strategies $(32.9 \%)$ were the most frequently used strategies among the participants, followed by memory $(26.2 \%)$, metacognitive $(17.7 \%)$, social $(11.9 \%)$, affective $(7.9 \%)$, and cognitive (3.4\%) strategies respectively.

Table 6. Descriptive statistics of participants' learning style preferences

\begin{tabular}{lllll}
\hline Learning style & Frequency & Percent & Valid Percent & Cumulative Percent \\
\hline Kinesthetic & 58 & 17.7 & 17.4 & 17.7 \\
Auditory & 65 & 19.8 & 19.8 & 37.5 \\
Visual & 205 & 62.5 & 62.5 & 100 \\
\hline
\end{tabular}

As Table 6 shows, visual learning style $(62.5 \%)$ was the most frequently preferred learning style among participants, followed by auditory (19.8\%), and kinesthetic (17.7\%) learning styles respectively.

Table 7. Descriptive statistics of participants' language learning strategy use by their learning styles

\begin{tabular}{llllllllll}
\hline & \multicolumn{3}{l}{ Kinesthetic } & \multicolumn{3}{l}{ Auditory } & \multicolumn{1}{l}{ Visual } \\
\cline { 2 - 10 } & Mean & \pm & SD & Mean & \pm & SD & Mean & \pm & SD \\
\hline Memory & 2.9 & \pm & 0.6 & 3.0 & \pm & 0.7 & 3.0 & \pm & 0.7 \\
Cognitive & 2.7 & \pm & 0.7 & 2.7 & \pm 0.8 & 2.5 & \pm & 0.8 \\
Compensation & 3.1 & \pm & 0.8 & 3.2 & \pm 0.8 & 3.0 & \pm & 0.9 \\
Metacognitive & 2.9 & \pm & 0.8 & 2.9 & \pm 1.0 & 2.8 & \pm & 1.0 \\
Affective & 2.5 & \pm & 0.8 & 2.7 & \pm 0.8 & 2.5 & \pm 0.8 \\
Social & 2.8 & \pm & 0.8 & 2.9 & \pm 0.7 & 2.8 & \pm 0.8 \\
\hline
\end{tabular}


As Table 7 shows, the participants reported using language learning strategies at a medium level by their learning styles.

Table 8. Correlation coefficient between learning strategies and and learning style preferences

\begin{tabular}{llll}
\hline $\mathrm{r}$ & Kinesthetic & Auditory & Visual \\
\hline Memory & $0.15^{*}$ & $0.31^{*}$ & $0.26^{*}$ \\
Cognitive & $0.19^{*}$ & $0.27^{*}$ & $0.15^{*}$ \\
Compensation & $0.17^{*}$ & $0.24^{*}$ & $0.17^{*}$ \\
Metacognitive & $0.17^{*}$ & $0.25^{*}$ & $0.18^{*}$ \\
Affective & 0.10 & $0.24^{*}$ & $0.17^{*}$ \\
Social & $0.17^{*}$ & $0.27^{*}$ & $0.21^{*}$
\end{tabular}

${ }^{*} \mathrm{p}<0.05$; Significant relationship between variables.

There were significant positive correlations between kinesthetic learning style preference and the use of memory $(\mathrm{r}=0.15)$, cognitive $(\mathrm{r}=0.19)$, compensation $(\mathrm{r}=0.17)$, metacognitive $(\mathrm{r}=0.17)$, and social strategies $(\mathrm{r}=0.17)$, $(\mathrm{p}<0.05)$. In addition, auditory learning style revealed a significant positive relationship with the use of memory $(\mathrm{r}=0.31)$, cognitive $(\mathrm{r}=0.27)$, compensation $(\mathrm{r}=0.24)$, metacognitive $(\mathrm{r}=0.25)$, affective $(\mathrm{r}=0.24)$, and social strategies $(\mathrm{r}=0.27),(\mathrm{p}<0.05)$. The analysis also showed a significant positive correlation between visual learning style preference and the use of memory $(\mathrm{r}=0.26)$, cognitive $(\mathrm{r}=0.15)$, compensation $(\mathrm{r}=0.17)$, metacognitive $(\mathrm{r}=0.18)$, affective $(\mathrm{r}=0.17)$, and social strategies $(\mathrm{r}=0.21),(\mathrm{p}<0.05)$.

\section{Discussion}

This study investigated the relationship between university students' learning style preferences and language learning strategy use. The Pearson's correlation coefficient was used to determine the relationship between learning styles and language learning strategies. The results of the study revealed significant positive relationships between students' learning style preferences and language learning strategy use. When the results are examined in detail, it was evident that, auditory and visual learning styles had significant positive relationships with all six language learning strategy categories. Also, kinesthetic learning style had a significant positive relationship with all language learning strategy categories except affective strategies category. Based on these results, it can be asserted that learning styles significantly influence learners' choice of language learning strategies.

In literature, there are some studies, though not extensive, which investigated the relationships between learning styles and language learning strategies. The result of this study with regard to the significant positive relationship between learning styles and language learning strategies is compatible with those of previous studies (Al-Hebaishi, 2012; Baghban, 2012; Ehrman \& Oxford, 1988; Ehrman \& Oxford, 1990; Jie \& Xiaoqing, 2006; Nosratinia, Mojri, \& Sarabchian, 2014; Rossi-Le, 1989; Sahragard, Khajavi, \& Abbasian, 2016; Shi, 2011; Tsai, 2012). The study conducted by Rossi-Le (1989) is one of the few studies investigating the relationship between perceptual learning style preferences and language learning strategies in learning a second language. The researcher found significant relationships between learning styles and language learning strategies and reported that the strongest correlation existed between visual learning style and visualization strategies. In a similar way, Sahragard et al. (2016) found significant relationships between language learning strategies and perceptual learning styles. The findings of this study with regard to the significant positive relationships between perceptual learning styles and language learning strategies lend support to the study conducted by Rossi-Le (1989) and Sahragard et al. (2016). Tsai (2012) found that reading strategies were highly correlated with learning styles in an EFL setting. Ehrman and Oxford (1988) concluded that gender and occupation have an important effect on learning strategy use. Also, they found that phychological types (extraversion, introversion, intuition, sensing) have relationships with language learning strategies. The relationship between learning styles and strategies could be attributed to the fact that learners who have different learning styles use learning strategies which are related to their preferred learning styles (Green \& Oxford, 1995). These relationships can also be illuminated by Oxford's (1990) explanation that general learning style has a very strong effect on students' choice of language learning strategies.

The results of this study, however, are not consistent with few studies. For example, in a study by Rahimi et al. 
(2008), the effect of proficiency, motivation, learning style, gender, and years of language study was investigated on learners' strategy use. It was found that only three variables, namely proficiency level, motivation and years of language study significantly predicted learners' language learning strategy use. So, in contrast to the findings in this study, Rahimi et al. (2008) found no significant relationship between learning styles and language learning strategies. Also, Wang (2012) found no significant differences among different learning styles groups in learning strategy use. Hsu and Chen (2016) found that most learning styles did not influence learners' selection of learning strategies. Nevertheless, the authors recommend that teachers should take learning ways into consideration in learning-teaching process.

Along with the primary objective of this study, which was to analyze the relationship between learning styles and language learning strategies, the data permitted us to identify learners' learning styles and language learning strategies. Visual learning style (62.5\%) was the mostly preferred learning style among participants, followed by auditory $(19.8 \%)$, and kinesthetic $(17.7 \%)$ learning styles respectively. When the literature was reviewed, it was noted that visual learning is preferred by large proportions of learners (Oxford, 1990; Psaltou-Joycey \& Kantaridou, 2011; Reid, 1987). With regard to language learning strategies, it was found that compensation (32.9\%), memory (26.2\%), and metacognitive (17.7\%) strategies were the most frequently used strategies, while cognitive (3.4\%) strategies were the least used strategies among the participants of this study. Through a literature review, one can find out that many factors influence language learning strategy use such as proficiency level, age, gender, motivation, and learning styles among others (Green \& Oxford, 1995; Ehrman \& Oxford, 1988; Magogwe \& Oliver, 2007; Oxford, 2003). Also, Oxford and Burry-Stock (1995) indicate that students from different cultural backgrounds and different countries use different language learning strategies. These factors can explain the differences in language learning strategy use. However, as it was mentioned cognitive strategies (practicing, receiving and sending messages, analyzing and reasoning, creating structure for input and output) were the least preferred strategies among the participants. It is an interesting finding because Oxford (1990) describes them as the strategies which are "essential in learning a new language" and explains that cognitive strategies have a common function which is described as "manipulation or transformation of the target language by the learner" (p. 43). Based on this finding, it could be inferred that students need training in terms of the use of cognitive strategies in learning contexts. Compensation strategies such as guessing or overcoming limitations in speaking and writing are found to be the most preferred strategies among the participants in this study. This result of the study can be interpreted by Oxford's (1990) explanation that less proficienct language learners as in this study need compensation strategies more than proficient learners because they have lack of grammar or vocabulary knowledge compared with skilled learners. So, it is thought to be essential for the participants to use compensation strategies which help them understand the target language and also produce it orally or in writing even if they have inadequate knowledge.

The findings have some implications for learning-teaching process. Based on the results of this study, it is recommended that teachers should be aware of students' learning styles and language learning strategies in learning-teaching process to facilitate learning. Green and Oxford (1995) address the issue in terms of individual differences and remark the importance of overcoming negative factors with regard to individual differences in the classroom by taking these individual characteristics such as learning strategies into account and state that "such knowledge is power" (p. 292) for teachers. Also, learning styles and strategies are thought among the main learner differences in L2 learning context (Ehrman et al., 2003). Wong and Nunan (2011) conclude that learning styles and strategies are complex phenomenons and so the authors recommend that teachers should teach students "learning-how-to-learn" (p. 153) so that learners can expand their learning styles and strategies. Along these lines, it is recommended to identify learners' styles and strategies in language classes so that teachers can be able to address students' styles and strategies and also stretch their learning styles and expand language learning strategy use as well.

It is known that there are complex interactions between learners' learning styles and language learning strategies (Rossi-Le, 1989). Because learning styles and learning strategies seem to be linked, it is important to create ESL courses that incorporate style and strategy training (Rossi-Le, 1995). So, it is important to take learning styles into consideration during language learning strategy training in language classes. In the same way, Oxford (2003) advocates strategy teaching matching learners' style preferences.

As a conclusion, the findings of the current study suggest that there are significant relationships between perceptual learning styles and language learning strategies in an EFL context. In other words, perceptual learning styles play an important role in EFL learners' language learning strategy use. Further research is required to investigate any possible relationships between learning styles and strategies in other levels of education and in different contexts. Finally, the effect of some other individual factors such as performance, context, gender, field 
of study among others on the use of language learning strategies can be examined. Moreover, the efficacy of learning style-based strategy training can be investigated in order to better understand the influence of learning styles on language learning strategy use.

\section{References}

Al-Hebaishi S. M. (2012). Investigating the relationship between learning styles, strategies and the academic performance of Saudi English majors. International Interdisciplinary Journal of Education, 1(8), 510-520. https://doi.org/10.12816/0002890

Baghban, Z. Z. V. (2012). The relationship between Iranian English language learners' learning styles and strategies. Journal of Language Teaching and Research, 3(4), 771-777. http://dx.doi.org/10.4304/j1tr.3.4.771-777

Brown, H. H. (2000). Principles of language learning and teaching (4th ed.). White Plains, NY: Longman.

Chamot, A. U. (2004). Issues in langusge learning strategy research and teaching. Electronic Journal of Foreign Language Teaching, 1(1), 14-26.

Cesur, M. O., \& Fer, S. (2007). What is the validity and reliability study of the Strategy Inventory of Language Learning?. Yüzüncü Yll Üniversitesi Ĕgitim Fakültesi Dergisi, 4(2), 49-74. Retrieved from http://efdergi.yyu.edu.tr/makaleler/cilt_IV/ii/mo_cesur.pdf

Ehrman, M., \& Oxford, R. (1988). Effects of sex differences, career choice, and psychological type on adult language learning strategies. Modern Language Journal, 72(3), 253-265. http://dx.doi.org/10.2307/327503

Ehrman, M., \& Oxford, R. (1990). Adult language learning styles and strategies in an intensive training setting. Modern Language Journal, 74(3), 311-327. http://dx.doi.org/ 10.1111/j.1540-4781.1990.tb01069.x

Ehrman, M. E., Leaver, B. L., \& Oxford, R. L. (2003). A brief overview of individual differences in second language learning. System, 31, 313-330. http://dx.doi.org/10.1016/S0346-251X(03)00045-9

Ellis, R. (1994). The study of second language acquisition. Oxford: Oxford University Press.

Fewell, N. (2010). Language learning strategies and English language proficiency: An investigation of Japanese EFL university students. TESOL Journal, 2, 159-174. Retrieved from http://tesol-international-journal.com/wp-content/uploads/2013/11/A11V2_TESOL.pdf

Green, J. M., \& Oxford, R. (1995). A closer look at learning strategies, L2 proficiency, and gender. Tesol Quarterly, 29(2), 261-297. http://dx.doi.org/10.2307/3587625

Hsu, C.-W., Chen, S.-C. (2016). A study of EFL college students'learning styles and learning strategies. Journal of Modern Education Review, 6(1), 1-9. http://dx.doi.org/10.15341/jmer(2155-7993)/01.06.2016/001

Jie, L., \& Xiaoqing, Q. (2006). Language learning styles and learning strategies of tertiary-level English learners in China. Regional Language Centre Journal (RLCJ), 37(1), 67-90. http://dx.doi.org/10.1177/0033688206063475

Magogwe, J. M., \& Oliver, R. (2007). The relationship between language learning strategies, proficiency, age and self-efficacy beliefs: A study of language learners in Botswana. System, 35, 338-352. http://dx.doi.org/10.1016/j.system.2007.01.003

Nosratinia, M., Mojri, Z., \& Sarabchian, E. (2014). Exploring the relationship between EFL learners' language learning styles and strategies. International Journal of Language Learning and Applied Linguistics World (IJLLALW), 5(2), 253-264. Retrieved from http://www.ijllalw.org/finalversion5220.pdf

Oxford, R. L. (1990). Language learning strategies: What every teacher should know. Boston, MA: Heinle \& Heinle.

Oxford, R. L. (2001). Language learning styles and strategies. In M. Celce-Murcia (Ed.), Teaching English as a second or foreign language (pp. 359-366). Boston, MA: Heinle\&Heinle.

Oxford, R. L. (2003). Language learning styles and strategies: An overview. GALA, 1-25. Retrieved from http://web.ntpu.edu.tw/ language/workshop/read2.pdf

Peacock, M. (2001). Match or mismatch? Learning styles and teaching styles in EFL. International Journal of Applied Linguistics, 11(1), 1-20. http://dx.doi.org/10.1111/1473-4192.00001

Oxford, R. L., \& Burry-Stock, J. A. (1995). Assessing the use of language learning strategies worldwide with the $\mathrm{ESL} / \mathrm{EFL}$ version of the strategy inventory for language learning (SILL). System, 23(1), 1-23. 
http://dx.doi.org/10.1016/0346-251X(94)00047-A

Psaltou-Joycey, A., \& Kantaridou, Z. (2011). Major, minor, and negative learning style preferences of university syudents. System, 39(1), 103-112. http://dx.doi.org/10.1016/j.system.2011.01.008

Rahimi, M., Riazi, A., \& Saif, S. (2008). An investigation into the factors affecting the use of language learning strategies by Persian EFL learners. CJAL, 11(2), 31-60.

Reid, J. M. (1995). Preface. In J. Reid (Ed.), Learning styles in the ESL/EFL classroom (pp. viii-xvii). Boston, MA: Heinle and Heinle. https://doi.org/10.1017/cbo9781139172721.001

Reid, J. M. (1987). The learning style preferences of ESL students. Tesol Quarterly, 21(1), 87-111. https://doi.org/10.2307/3586356

Rossi-Le, L. (1989). Perceptual learning style preferences and their relationship to language learning strategies in adult students of English as a second language (Unpublished doctoral dissertation). Drake University, Des Moines, IA.

Rossi-Le, L. (1995). Learning styles and strategies in adult immigrant ESL students. In J. Reid (Ed.), Learning styles in the ESL/EFL classroom (pp. 118-125). Boston, MA: Heinle and Heinle Publishers.

Sahragard, R., Khajavi, Y., \& Abbasian, R. (2016). Field of study, learning styles, and language learning strategies of university students: Are there any relations? Innovation in Language Learning and Teaching. 10(3), 255-271. http://dx.doi.org/10.1080/17501229.2014.976225

Salahshour, F., Sharifi, M., \& Salahshour, N. (2013). The relationship between language learning strategy use, language proficiencylevel and learner gender. Procedia - Social and Behavioral Sciences, 70, 634-643. http://dx.doi.org/10.1016/j.sbspro.2013.01.103

Shi, C. (2011). A study of the relationship between cognitive styles and learning strategies. Higher Education Studies, 1(1), 20-26. http://dx.doi.org/10.5539/hes.v1n1p20

Şimşek, N. (2002). Big16 öğrenme biçemleri envanteri. Eğitim Bilimleri ve Uygulama, 1(1), 33-47. Retrieved from http://www.ebuline.com/pdfs/1Sayi/1-3.pdf

Tsai, Y.-R. (2012). Investigating the relationships among cognitive learning styles, motivation and strategy use in reading English as a foreign language. International Journal of Business and Social Science, 3(13), 188-197. Retrieved from http://www.ijbssnet.com/journals/Vol_3_No_13_July_2012/22.pdf

Wang, N. (2012). Relationship between English learning strategies and learning style preferences: An empirical study. Sino-US English Teaching, 9(9), 1502-1509. Retrieved from http://www.davidpublishing.com/davidpublishing/Upfile/11/2/2012/2012110203434376.pdf

Wong, L. L. C., \& Nunan D. (2011). The learning styles and strategies of effective language learners. System, 39, 144-163. http://dx.doi.org/10.1016/j.system.2011.05.004

Yilmaz, C. (2010). The relationship between language learning strategies, gender, proficiency and self-efficacy beliefs: A study of ELT learners in Turkey. Procedia - Social and Behavioral Sciences, 2(2), 682-687. http://dx.doi.org/10.1016/j.sbspro.2010.03.084

\section{Copyrights}

Copyright for this article is retained by the author(s), with first publication rights granted to the journal.

This is an open-access article distributed under the terms and conditions of the Creative Commons Attribution license (http://creativecommons.org/licenses/by/4.0/). 